\title{
KLF3 wt Allele
}

National Cancer Institute

\section{Source}

National Cancer Institute. KLF3 wt Allele. NCI Thesaurus. Code C162393.

Human KLF3 wild-type allele is located in the vicinity of $4 \mathrm{p} 14$ and is approximately $37 \mathrm{~kb}$ in length. This allele, which encodes krueppel-like factor 3 protein, is involved in the modulation of gene expression in erythrocytes. 